\title{
INDUSTRIAL BURNERS TESTING AND COMBUSTION EFFICIENCY ANALYSIS
}

\begin{abstract}
Pimenta, J., De Lima, L.C., Duarte, J.B.F, Macedo, R. M. Universidade de Fortalesa Centro de Cièncias Tecnologicer Curso de Engenharia Mectinica VTC-Nǘleo de Tecnotogiada Conteasão Av, Washingum Suares, 1321 Bairro Eutvon Quciro2 60811-905, Fortalera, Ceark, Brasi pimscntaes unifor.hr
\end{abstract}

\section{INTRODUCTION}

Combustion and its control is a primury impontince to the survival of our planet. Basically almost $80 \mathrm{G}$ of the human activities on earth relies on some kind of combustivn proces as for example, the generation of electricity, transportation. industries, commerce, and services. On the oher side of the beneficial aspects of combustion there is the associatod problem of environmental pollution. The major pollutants produced by combuxtion are unhurned and partially burned hydrocarbons, nitrogen oxides, carbon monoxides, sulphur oxides and particulates under various forms

Governmental regulations on emissions standard are being more and more stringent, depletion of fossil fuels is just on the rear-mirmr, and the competitiveness of the sloxhal new order demand scientists and engineers to be more focused on problems of combustion.
With the above related situation on mind, the University of Fortaleza through governmental help constructed the NTC (Combustion Technology Laboratory) a laboratory were the present work was carried cut. The experiments described hereafier are related with industrial burners performance testing, and represents the startup on research activities at the NTC, in the field of applied combustion.

Two barners were tested for different operating conditions, using an experimental combustion chamber. The experimental testing data was used in order to evaluate burners efficiency und emissions characteristics, according to air to fuel ratio.

Analysis of the acquired data and computed results are consistent with theoretical expected results, showing by this way that the methodology applied was adoquate 


\section{EXPERIMENTAL FACILITIES AND TESTING SET-UP}

Figures 1 and 2 show some views of the testing agparates used in this work. The main component is combustion chamber, equipped with all the atcessory components and control required for burners operation Although any gaseovus. fuel could be supplied to the chamber. only liquefied petroleum gas (L.PG) was thed in this unork.

The combustisn chamber has a eylindrical section with a diameter of $1600 \mathrm{~mm}$, a height of $2500 \mathrm{~mm}$, having a composed insulated wall with $200 \mathrm{~mm}$ thickness. The burner is mounted in the inferior section of the cylindrical section (as shown in Figs. 1 and 3). being connected to the gas and air supply/enotrot racks.

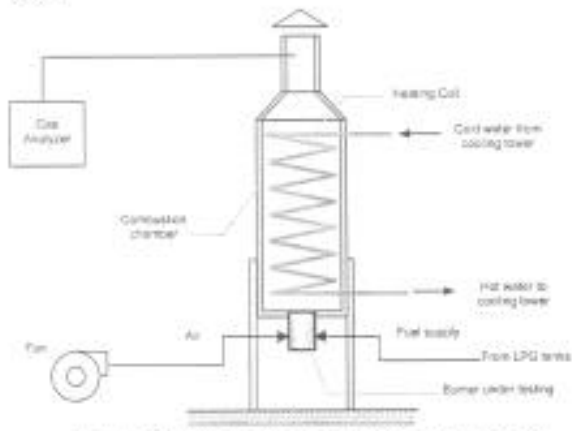

Fif. 1-Sctermatic view of the combustion lest bench

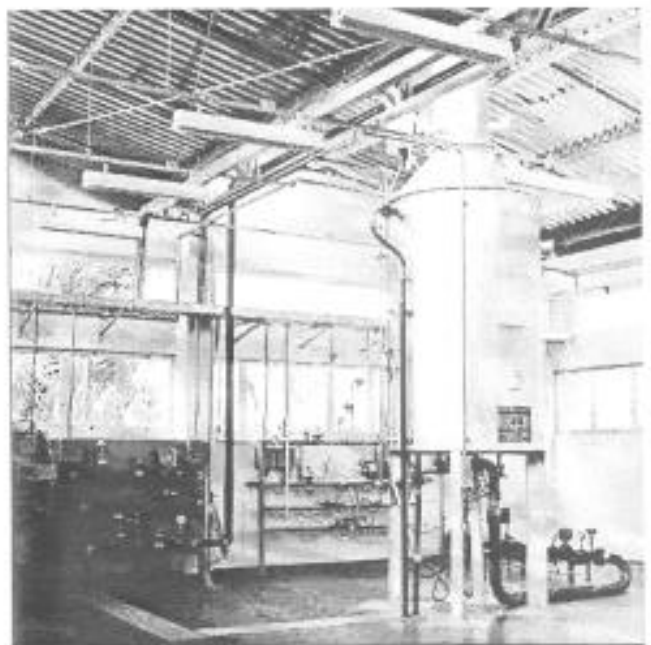

Fix 2. Gencral ricw of the combastion test bench.

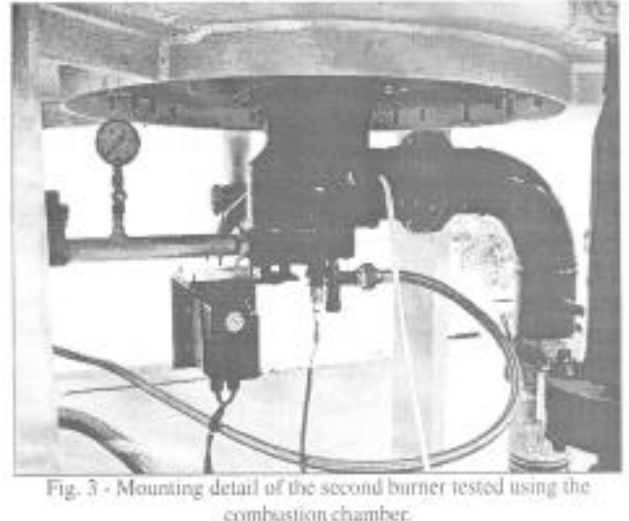

\begin{tabular}{|c|c|c|}
\hline & \\
\hline & Buner 1 & Bamer 2 \\
\hline 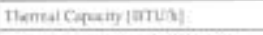 & 16002048 & 759.1609 \\
\hline 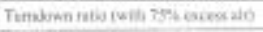 & His & - \\
\hline Thers kngh / heurneter [in] & $12.24: 4.12$ & 1230 \\
\hline Masients couss ar ( 16 ) & $3100-4700 \%$ & $=$ \\
\hline
\end{tabular}

Tahle 1- Main charackeristics of the bumers tesied.

Two industrial burners (Fig, 4) were tested accurding the procedure described hereafter. Table 1 lists main characteristics for each bumer.

A water heating coil is available inside of the cylindrical section of the chamber, in order to simulate useful heat coutpat. The coil is connected with a cooling tower forming a closed water network.

All the experimental data from testing was measared by $a$ instrumentation system consisting basically of type $K$ thermocouples, turbine fliow meters and pressure transmitters. All the analog signals from senser transmitters were acquired by a IXC based data acquisition and exntrol system handware.

Figure 5 below, sbuws a view of the PC screen developed within a commereial data acquisition and osntrol soffware, in order to assist experimental tests with the combustion chamber.

\section{THHORETICAL CONSIDERATIONS}

In this work, liquefied petroleum yas combustion is considered. Although L.PG composition consists of ethane, propane and butane, with different mixtures, a $100 \%$ propane composition was assumed in this wsork. Considering camplete propane combestion with a stoichiometric amount of air, the followine reaction equation can be exnosiderod.

$$
\mathrm{C}_{2} \mathrm{H}_{2}+(5)\left(\mathrm{O}_{2}+3,76 \mathrm{~N}_{2}\right) \rightarrow 3 \mathrm{CO}_{2}+4 \mathrm{H}_{2} \mathrm{O}+(5 \times 3,76) \mathrm{N}_{2}
$$

Combustion air composition is assumed $t$ be 21 percent $\mathrm{O}$, and 79 percent $\mathrm{N}_{2}$ (by volume). The stoichiometric air-fue ratio $\left(\mathrm{AF}_{\mathrm{cun}, \mathrm{si}}\right)$ for propane can be given by (Turns.2000).

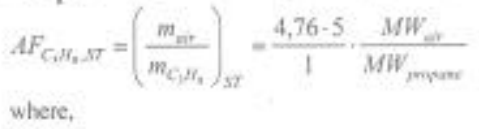

Engenharia Térmica, Ediçăo Especial, n. 2, 2002, p. 3-8 

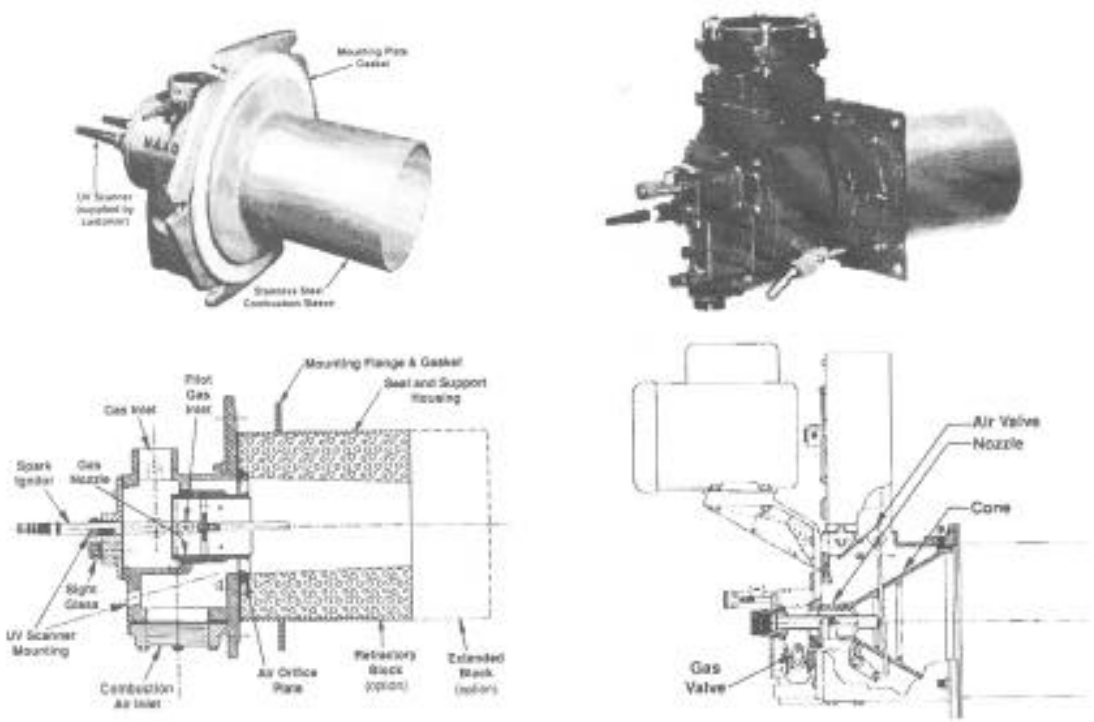

Fie. 4 - Burners 1 (keft) and 2 (right) tested in the experiments.

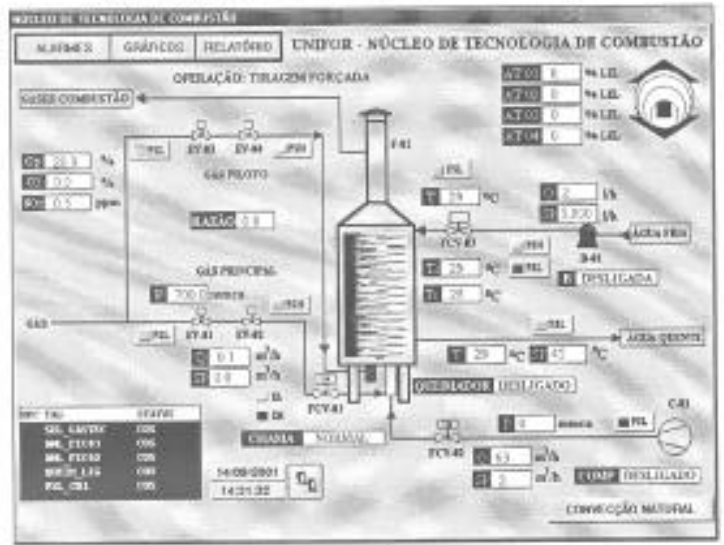

Fil 5 - Scneenshos of the PC based supervisory pancl.

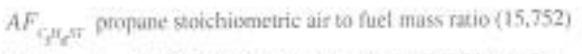

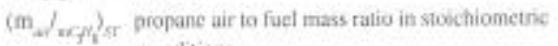
sunditions

$M W_{-}$air molecular weight $\quad(-28,85)$

$M W_{\text {piser }}$ propare molocular weight $\left.(-3,3,12,01)+\mathrm{B},(1,008)=44,004\right)$

The equivalence ratio $(\Phi)$ is definod by the ratio between stoichicmetric and actual uir-fuel ratios as,

$$
\Phi=\frac{A F_{C_{1} m_{1}, 3 t}}{A F_{C_{1} l_{3}, \Delta t}}
$$

where $A F_{\mathrm{CM} \text { ing }}$ Actrepresents the actual air fuel ratio.
According the value of $\Phi$, the fucl-air mixture muy be rich ( $\phi>1)$. lean $(\Phi<1)$, or stodchiometric ( $\Phi=1$ ). The percent excess air in actual combustion systems is obtainod with respect to $\Phi$, by making.

$$
E A_{\mathrm{s}}=\frac{(1-\Phi)}{\Phi} \cdot 100
$$

Considering an application of th Law energy conservation principle, to a control volume including the combustion chamber, as shown in Fig. 6. the following equation can be written (Borman, 1998).

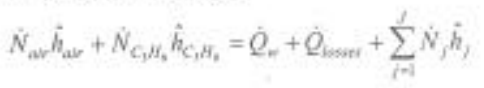




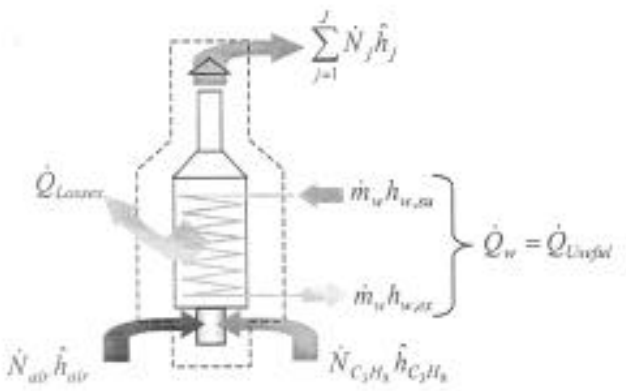

Fig. 6- Inergy halance for the combustion chamber cotrol volume

where, $\hat{N}_{w} \hat{h}_{\text {av }}$ and $\hat{N}_{5, h_{2}} \hat{h}_{C, \mu}$ curresponds to heat input from cosmbustion air and fucl respectively, and $\hat{Q}_{w}$ is the heat transfer rate to waser (useful heat). $\dot{Q}_{\text {was }}$ is the heat foswer from chamber walls, and $\sum_{j=1}^{N_{i}} \hat{h}_{j}$ is the heat output assuciated with combustion products.

In order to compute the combustion efficiency of the burners $\langle\eta\rangle$, useful heat output is taken as the heat inansfer rate to water in the heating cont $\left(\dot{Q}_{\mathrm{N}}\right)$. In this case, we simply have,

$$
\eta=\frac{\text { usefal heat output }}{\text { energy input }}=\frac{\dot{\phi}_{2}}{\dot{m}_{f} H H V}
$$

In the above equation. HHV represents the higher heating value of the fuel (for propane), $\dot{m}_{f}$ is the fuel mass flow rate. and $Q$, is calculated making.

$$
\dot{Q}_{v}=\dot{V}_{w} \cdot P_{w} \cdot C_{w} \cdot\left(\hat{T}_{w, \mathrm{a}}-T_{w, \mathrm{ma}}\right)
$$

where. $V_{*} P_{*} C_{*}\left(T_{w}-T_{-}\right)$, are the water volumetric flow rate, density, specific heat and temperature difference between coil inlet and oualet.

Heat losses from combustion chamber walls to the surroundings were exaluatod by considering free convection with ambient still air. The wall temperature of the chamber, was taken as an average absout $30 \times$ C (max), while for the ambient air, at average tempenature during the tests about $25^{\circ} \mathrm{C}$ (min.) was considered.

For these temperatures, the Grashof number is about 3. $40 \mathrm{E}^{10}$, which characterizes a turbulent flow condition. Then, a simplifted correlation for natural turbulent convection heat uransfer from a vertical cylinder (Holman, 83) was used, resulting in a convective heat transfer coefficient of $2.8 \mathrm{~W} / \mathrm{m}^{2}, \mathrm{~K}$. With this approach, heat losses from the chamber are of $873 \mathrm{~W}$; a quite small value compared with the useful beat output (less than I's apeox.)

A heat transfer analysis of the heating cxil was also developed in this work. Several tests with different water flow rates. as well as, enmbustion conditions were made, allowing us to investigate some correlation for overall heat transfer coefficient. Results about this are shown in next section.

\section{TESTING METHODOLOGY AND EXPERIMENTAL DATA}

The testing methodology is based in the adjust of 3 operating conditions : (i) L.JP flow rate, (i) combustion air flow rate and (iii) coil water flow rate. Several tests were performed for different operating conditions cumbining these parameters. Fig. 7 below shows an owerall viesw of the experiments carried out with respect to the range of air and fuel flow rates.

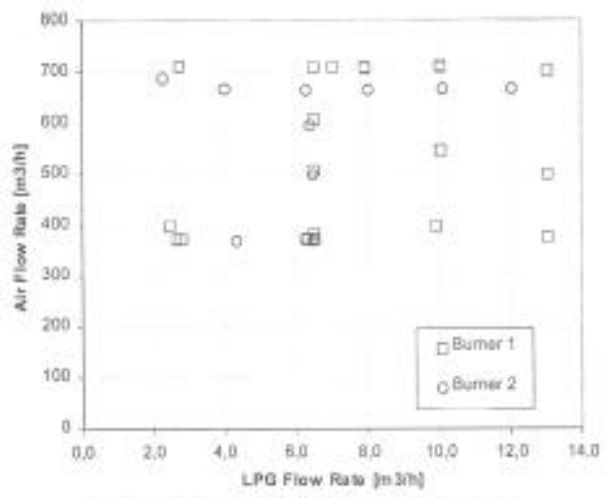

Fig 7 - Air and fuct flow rate ranges for the lests.

Basically the vesting procedure consists of adjusting an operating condition, i.e., setting the three desired parameters. and to wait until steady state establishment. Once stable operation is verified, some time interval is allowed in order to register a representative amount of data, before changing operating parameters for the next testing condition. Fig. 8 shows a typical testing run where air and fuel flow rate was changed for different experimental conditions.

\section{EXPERIMENTAL RESULTS}

With average measuremenis for each steady state operating conditions, the efficiency for each burner was calculated from Ex- (6) and plotted against the equivalence ratio ( $($ ) as shown in Figure 9. As it can be seen, cumbustion efficiency increases with $\phi$, and tends $t s$ sone maximum stable value as $\Phi$ tends to unity.

Concerning efficiency of combustion against the equivalence ratio for bosth tested burners, as shown in the Fig. 9. its behavior is as expected, that is. For a lean mixture of fuel and air, the combustion efficiency will be lower than the maximum efficiency which will be attained when $\Phi$ equals unity.

In this article technical details of each burner will not be considered profoundly although as can be seen in Fig. 9, the cxmbustion efficiency of the burner I shows a more harmonious tendency than the burner 2. Both are of premixed type burners However, burner 2 shows a more consistent combustion efficiency than burner 1 . This behavixur can probably be due to the way the air injected into the burner mixing chamber. In the casc of burner 1 , aic enters the chamber in a swirled way and

Engenharia Térmica, Edị̧āo Especial, n. 2, 2002, p. 3-8 

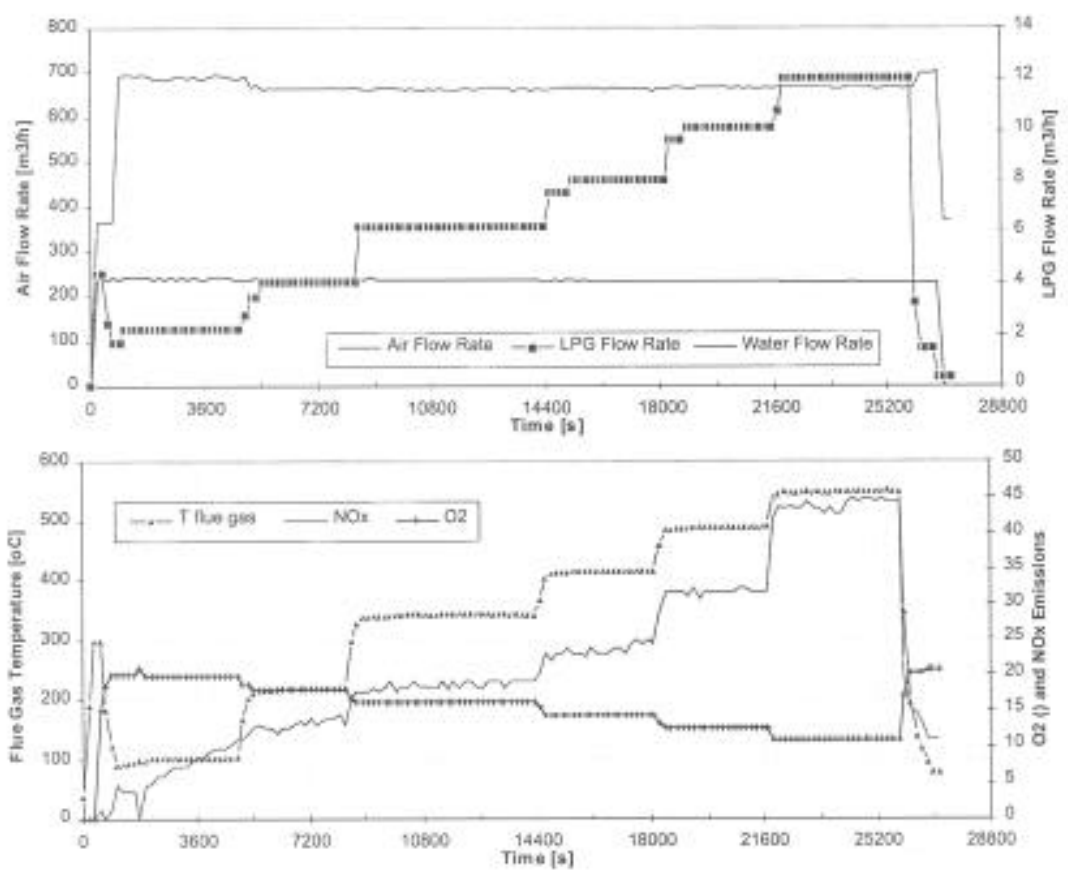

Fif 8 - Changes of selected variahles during a typical vesting run. Above: LPG, air and water fow rates. Below: Combastiva products semperatures, $\mathrm{NOx}$ and $\mathrm{O}_{2}$ emissions.

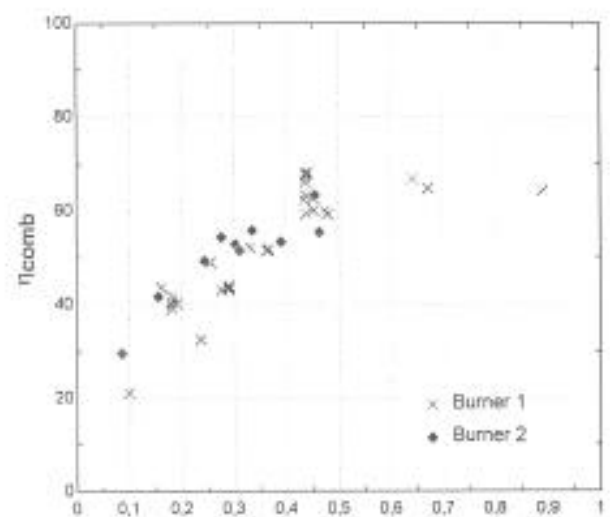

$\Phi$

Fig 9. Combustion efficiency as a function of equivalence fario.

as for burner 2 , air enters laterally through oxifices in the wall of a conical secticon.

Although the main goal of the experiments is the combustion siudy, additional analysis was considered for the heatine coil installed inside the combustion chamber.

Such data allow us to investigate pussible correlation involving heat transfer cuefficients, water flow and combustion condition.

Figure 10 shows the useful heat liberated by burner

Engenharia Térmica, Ediçăo Especial, n. 2, 2002 p., 3-8

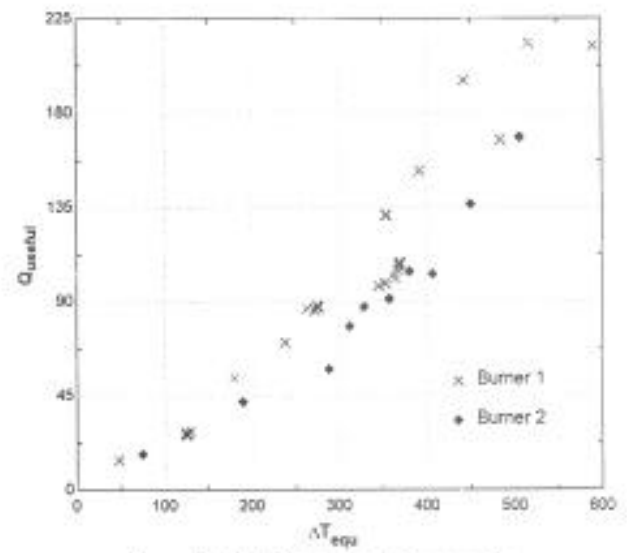

Figure 10 - Useful heat output ctunge with equivalent temperature difference.

against equivalent temperature difference (considering temperatures for flue gas, water inlet and cutlet). Such kind of representation allow to identify an overall heat transfer coefficient foe the water heating coil about $318 \mathrm{~W} / \mathrm{K}$. Although, as seen in Fiy. 9, burner 2 showed a harmonious behaviour of efficiency against equivalent ratio, burner 1 delivers a more pronounced useful heat as a function of $\Delta T_{\text {a }}$ when compared with bumer 2 . This behaviour ean be influential on the way the 
PIMENTA, J-; et al. Industrial burners testing and combustion.
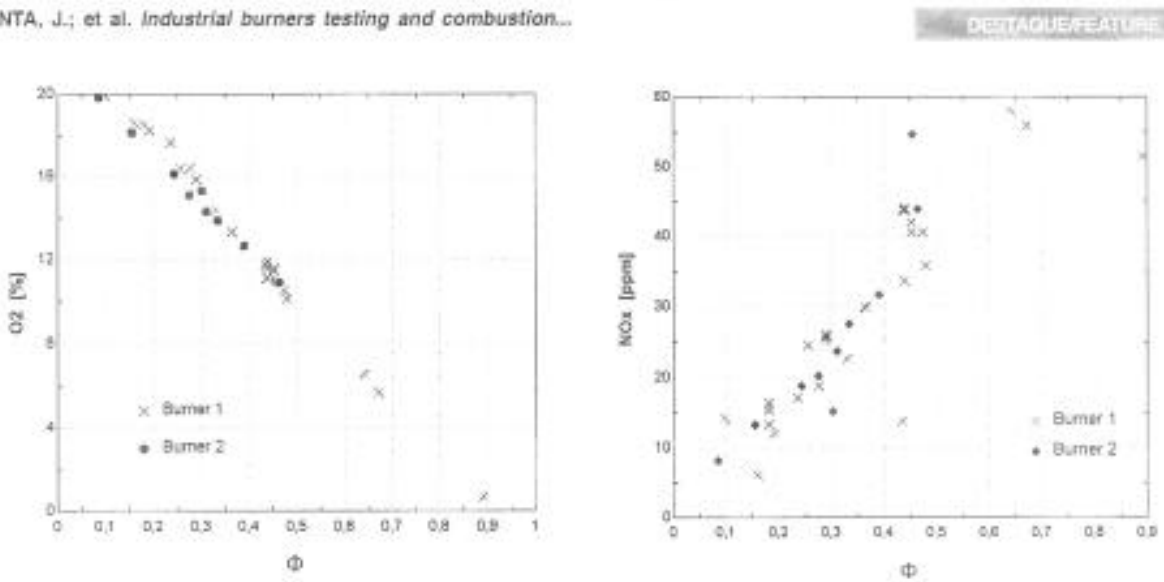

Figafe 11- Oxygen and (Left) nitrogen oxides (right) measured emissions as a function of the equivalence ratio.

hurner is used, that is, the way the burner heats the process. On the case in which the delivered heat must be under strict control, the design of burner 2 will be appropriated, and, in the uther case, the design of burner 1 will be recommended.

Figgure 11 below presents a view of $\mathrm{O}_{2}$ and NOx emissions measured durine the tests, as a function of the cquivalence ratio (Ф). The observed dectease of oxygen presente in combustion products, accordingly $\Phi$ inereases, is in agreement with basic combustion theory and simply reflects the change from a excess ai condition ( $\Phi<1)$ to a stoichiometric one $(0=1)$. The opposite behaviour is also expected for emission of NOx.

From Fig. 11. it is interesting to see that both burners have practically the same behaviour in the decrease of oxygen emission. Naturally the emission of $O_{2}$ as excess air pereentage, express the needs of different technologies and applications as for example, agricultural products drying, but in any case for such application both burner would be appropriated. The same is not true when the centrol of NOx emission is desirable since. as tan be seen in Fig. 11, the burner 2, seems to show better conditions to accept technical modifications in order to redoce nitrogen oxides emissions.

\section{CONCLUSIONS}

A resting methodology for burners efficiency analysis was presented, using an experimental taboratory tombastion chamber. Afler analysis of the acquirod data, classical equations on combustion analysis were used in order to exmpute performance parameters. The experimental results obtained are consistent with theoretical expected results, allowing to consider the methodology applied as adequate.

\section{ACKNOWLEDGEMENTS}

The authors would express his acknowledgements to the FINEP (Financiadora de Listudos e Projetus) for the financial support which allowed to create the laboratory where these work was developed.

\section{REFERENCES}

Bolman, J.P., 1983, Transjerência de Calor, McGran Hill do Brasel.

Borman, G, L.. Ragland. K.W., 1998, Combirstion Euginecring. McGuw-Hill International Editions.
Tums, S.R., 2000, An Introduction so Combustion, 2"it Fd. McCiraw. Hill Insernational Eutitions. 